\title{
Release of Soluble Receptors for Tumor Necrosis Factor in Clinical Sepsis and Experimental Endotoxemia
}

\author{
Tom van der Poll, Jaap Jansen, Diana van Leenen, \\ Marijke von der Möhlen, Marcel Levi, Hugo ten Cate, \\ Harald Gallati, Jan W. ten Cate, and \\ Sander J. H. van Deventer
}

\author{
Academic Medical Center, Department of Internal Medicine, and Center \\ for Hemostasis, Thrombosis, Atherosclerosis, and Inflammation \\ Research, University of Amsterdam, Netherlands; Hoffmann-La Roche, \\ Pharmaceutical Research-New Technologies, Basel, Switzerland
}

To assess the role of tumor necrosis factor (TNF) in the appearance of soluble TNF receptors (sTNFRs), 20 consecutive patients with a clinical diagnosis of sepsis were studied as were 7 chimpanzees after administration of endotoxin $(4 \mathrm{ng} / \mathrm{kg})$ with or without pentoxifylline. The patients had markedly elevated serum levels of sTNFR-p55 and sTNFR-p75 compared with healthy controls $(P<.0001$ for both receptors). The levels of both soluble receptors correlated with simultaneously measured immunoreactive TNF concentrations (p55: $r=.63, P<.01 ; \mathrm{p} 75: r$ $=.69, P<.001)$. In the chimpanzees, endotoxin induced subsequent rises in the serum concentrations of TNF and sTNFRs. Although pentoxifylline reduced the TNF response to intravenous endotoxin to $20 \%(P<.05)$, the appearance of sTNFRs was only moderately inhibited (sTNFRp55 to $79 \%$ on average, $P<.05$; sTNFR-p 75 to $77 \%, P=.12$ ). These results indicate that TNF either does not play an important role in the appearance of sTNFRs in systemic infection or that a small amount of TNF remaining in the circulation after some bacterial challenges is sufficient to preserve the secretion of its soluble receptors.

Sepsis is a syndrome characterized by hypotension, vascular leakage, and failure of multiple organs. Tumor necrosis factor (TNF) is an important factor for initiation of the septic syndrome [1]. Massive induction of TNF synthesis, resulting in high concentrations of the protein in the circulation, is a prerequisite for the development of shock and multiple organ failure in experimental sepsis in animals [2]. In patients with sepsis, the extent of systemic TNF release correlates strongly with mortality rates $[3,4]$. Administration of TNF to animals or humans reproduces many of the features of septicemia $[5,6]$. Recently, naturally occurring inhibitors of TNF activity have been found in the urine of normal individuals and febrile patients and in the serum of patients with renal insufficiency [7-11]. These host mediators, originally termed TNF-binding proteins, have subsequently been identified as the soluble extracellular domains of the 55- and 75-kDa membrane-bound TNF receptors [12-16]. Soluble

Received 22 February 1993; revised I June 1993.

Presented in part: 4th International TNF Congress and Related Cytokines, 2-6 May 1992. Veldhoven, Netherlands (Eur Cytokine Network 1992;3:214; abstract D-5).

Informed consent was obtained from all patients or from their relatives. The chimpanzee studies were conducted according to guidelines of the Dutch law for animal experiments and the American Physiological Society.

Financial support: Dutch Thrombosis Foundation; T.v.d.P. is a fellow of the Netherlands Organization for Scientific Research; S.J.H.v.D. is a fellow of the Royal Dutch Academy for Arts and Sciences.

Reprints or correspondence: Dr. Tom van der Poll, Academic Medical Center, Dept. of Internal Medicine, Rm. F4-222, Meibergdreef 9, 1105 AZ Amsterdam. Netherlands.

The Journal of Infectious Diseases 1993;168:955-60 (C) 1993 by The University of Chicago. All rights reserved. $0022-1899 / 93 / 6804-0022 \$ 01.00$
TNF receptors (sTNFR-p55 and -p75) compete with the membrane receptors for binding of free TNF and may therefore have physiologic importance for the regulation of TNF activity. Indeed, in vitro experiments have revealed that TNF-binding proteins can block various biologic activities of TNF $[8,10,11,17]$.

Intravenous administration of endotoxin has been widely used to study the early events of the host response to sepsis. Injection of endotoxin induces a rise in the serum levels of TNF, peaking after $90 \mathrm{~min}[17,18]$, which is followed by the appearance of sTNFRs [17]. Because of the subsequent appearances of TNF and its inhibitors, it has been suggested that the cytokine is involved in the regulation of its own activity in endotoxemia. This hypothesis is supported by the fact that TNF is capable of inducing the production of a TNF-binding protein in vitro [12] and, when combined with subcutaneous injections of interferon- $\gamma$, in cancer patients in vivo [19]. Moreover, in children with severe meningococcemia, the appearance of TNF seems to precede the appearance of the soluble receptors [20]. We assessed the possible role of TNF as an intermediate factor in the release of sTNFRs in sepsis.

\section{Materials and Methods}

Study populations and design. Blood was obtained from 20 consecutive patients ( 15 men, 5 women) admitted with a clinical diagnosis of sepsis to the Intensive Care Unit, Academic Medical Center, Amsterdam. Ages were 29-79 years (mean, 58.3). Criteria for a diagnosis of sepsis were as follows [21]: fever or hypothermia ( $>38.3$ or $<35.6^{\circ} \mathrm{C}$ ); tachycardia ( $>90$ beats/ $\min$ in the absence of $\beta$-blockade) and tachypnea (respiration 
$>20 /$ min or need for mechanical ventilation); and either hypotension (systolic blood pressure $\$ 90 \mathrm{~mm} \mathrm{Hg}$ or a sustained drop in systolic pressure $\geqslant 40 \mathrm{~mm} \mathrm{Hg}$ in the presence of an adequate fluid challenge and in the absence of antihypertensive agents) or two of the following six signs of systemic toxicity or peripheral hypoperfusion-unexplained metabolic acidosis $(\mathrm{pH} \leqslant 7.3$, base deficit $>5 \mathrm{mmol} / \mathrm{L}$, or an elevated plasma lactate level); arterial hypoxia $\left(\mathrm{PO}_{2} \leqslant 75 \mathrm{~mm} \mathrm{Hg}\right.$ or $\left.\mathrm{FIO}_{2}<250\right)$; acute renal failure (urinary output $<0.5 \mathrm{~mL} / \mathrm{kg} / \mathrm{h}$ ): elevated prothrombin or partial thromboplastin time or reduction of the platelet count to less than half the baseline value or $<100,000$ platelets $/ \mathrm{mm}^{3}$; sudden decrease in mental acuity; and cardiac index of $>4 \mathrm{~L} / \mathrm{m}^{2}$ with systemic vascular resistance of $<800 \mathrm{dyn} \mathrm{s} / \mathrm{cm}^{5}$.

In addition to these human experiments, 7 healthy adult chimpanzees (Pan troglodytes) were studied after either intravenous injection $(n=4)$ of endotoxin $(4 \mathrm{ng} / \mathrm{kg}$ : lot EC-5, Escherichia coli O113; provided by D. Hochstein, Bureau of Biologics, US Food and Drug Administration, Bethesda, MD) or injection of the same endotoxin dose in combination with an intravenous infusion of pentoxifylline ( $n=3$ : Trental; Hoechst, Amsterdam). A total of $500 \mathrm{mg}$ of pentoxifylline was given in $3 \mathrm{~h}$, starting $30 \mathrm{~min}$ before the administration of endotoxin. The chimpanzees were from the primate colonies of the TNO-ITRI Primate Center, Rijswijk, Netherlands, and the Laboratory for Experimental Medicine and Surgery in Primates, New York University School of Medicine, New York. All animals had normal routine laboratory examinations. They were sedated with ketamine chloride (Ketalar; Parke-Davis, Amsterdam) and, after intubation, kept under general anesthesia with nitrous oxide and halothane (Halothan; Hoechst). All animals were studied for $5 \mathrm{~h}$ after the injection of endotoxin. Other than a mild febrile response, there were no adverse effects and all animals were returned to their cages in good health after the experiments. The chimpanzee studies were part of simultaneous investigations on the effects of pentoxifylline on endotoxin-induced neutrophil activation (not reported here).

Sampling and assays. Patients with clinical sepsis were studied at admission. Chimpanzee venous blood samples were obtained just before the endotoxin injection and at $0.5,1.0,1.5$, $2.0,3.0,4.0$, and $5.0 \mathrm{~h}$ thereafter. Serum was prepared immediately, and samples were stored at $-70^{\circ} \mathrm{C}$ until analyzed. sTNFR-p 55 and -p 75 were measured with enzyme-bound immunologic assays (Hoffmann-La Roche) [20]. Microtiter plates (Maxisorp; Nunc, Roskilde, Denmark) were coated overnight at room temperature with TNF-binding noninhibitory monoclonal antibodies against TNFR-p55 (clone htr-20) or TNFR-p75 (clone utr-4) $[22,23]$. Subsequently, the coated wells were washed, and the remaining protein-binding capacity of the wells was saturated with $1 \%$ bovine serum albumin in $200 \mathrm{~m} M$ TRIS/ $\mathrm{HCl}, \mathrm{pH} 7.5$, and $0.02 \%$ Kathon. After the storage buffer was discarded, samples diluted $1: 5$ in $0.1 M$ sodium phosphate buffer, pH 7.25, containing $10 \%$ fetal bovine serum, $0.1 \%$ phenol, $0.1 \%$ Tween 20 , and $0.02 \%$ Kathon were added to the wells. Standard curves were constructed with recombinant sTNFR-p55 or -p 75. Next, peroxidase-conjugated recombinant human TNF was added, and the mixtures were incubated for 2 days at $4^{\circ} \mathrm{C}$. After wells were washed four times with distilled water, $0.05 \%$ Tween 20 and $o$-phenyldiamine dihydrochloride substrate were added and incubated for 15-20 min. The reaction was stopped with $\mathrm{H}_{2} \mathrm{SO}_{4}$ and read at $490 \mathrm{~nm}$.

The specificity of the assays has been confirmed by experiments in which the binding of the detecting recombinant TNF to sTNFRs could be prevented either by addition of an excess $(20 \mu \mathrm{g} / \mathrm{mL})$ of unlabeled TNF or by replacing the anti-TNFR monoclonal antibodies by nonspecific antibodies [24]. In addition, the linearity of the assays was verified using natural TNFRs from cell lysates of HL-60 cells and by recombinant TNFR-p 55 and $-p 75$. The concentrations of both sTNFRs were calculated from the amount of bound labeled TNF using a $1: 1$ binding stoichiometry between TNF and sTNFR. The concentrations calculated in this way were consistent with those obtained by using recombinant sTNFRs as the standard [24]. The serum concentrations of TNF were determined by an assay (IRMA; Medgenix, Fleurus, Belgium). This assay measures TNF regardless of whether it is complexed with its soluble receptors and is therefore not disturbed by high circulating concentrations of sTNFRs [25].

Serum TNF activity was determined in a biologic assay using WEHI-164 mouse fibrosarcoma cells [26]. They were collected during logarithmic growth and suspended at a concentration of $4 \times 10^{5} / \mathrm{mL}$ in RPMI 1640 containing $10 \%$ fetal calf serum and actinomycin $\mathrm{D}(1 \mu \mathrm{g} / \mathrm{mL})$. Volumes of the suspension $(50 \mu \mathrm{L})$ were added in triplicate to equal parts of the serum sample to be tested (starting at a 1:10 dilution) in flat-bottom 96-well plates (Maxisorp; Nunc) and incubated at $37^{\circ} \mathrm{C}$ for $18 \mathrm{~h}$. Cytotoxicity was assessed using the 3-(4,5-dimethylthiazol-2-yl)-2,5-diphenyl tetrazolium bromide (MTT) cytotoxicity assay. After addition of $20 \mu \mathrm{L}$ of MTT $(5 \mathrm{mg} / \mathrm{mL}$ in PBS) to each well and incubation at $37^{\circ} \mathrm{C}$ for $4 \mathrm{~h}, 100 \mu \mathrm{L}$ of lysis buffer $(20 \% \mathrm{wt} / \mathrm{vol}$ SDS in 50\% dimethyl fluoride) was added; incubation was continued overnight, and absorbance was read at $578 \mathrm{~nm}$. Concentrations of TNF are given in picograms per milliliter; recombinant human TNF (provided by Bayer, Wuppertal, Germany) was used as the reference standard. The detection limit of the assay is $1 \mathrm{pg} / \mathrm{mL}$ (i.e., in serum, $10 \mathrm{pg} / \mathrm{mL}$ ).

Statistical analysis. All values are given as means $\pm \mathrm{SE}$. The differences in results between patients with sepsis and normal humans were analyzed by Wilcoxon rank sum test. Correlations were calculated using the Pearson test. In the chimpanzee studies, differences in results obtained with endotoxin alone and with endotoxin combined with pentoxifylline were analyzed using analysis of variance. $P<.05$ represented a significant difference.

\section{Results}

Patients with clinical sepsis. Admission Apache II scores of the 20 patients with clinical diagnoses of sepsis ranged from 18 to $47(31 \pm 1)$. Overall mortality of these patients was $50 \%$. Blood cultures were positive in 8 patients (gramnegative bacteria, 7; yeast, 1). Fifteen patients had positive cultures from various loci (9, gram-negative bacteria; 4 , gram-negative and -positive bacteria; 2 , gram-negative bacteria and yeasts). In 2 patients, all cultures remained sterile. These patients were not excluded because their clinical 


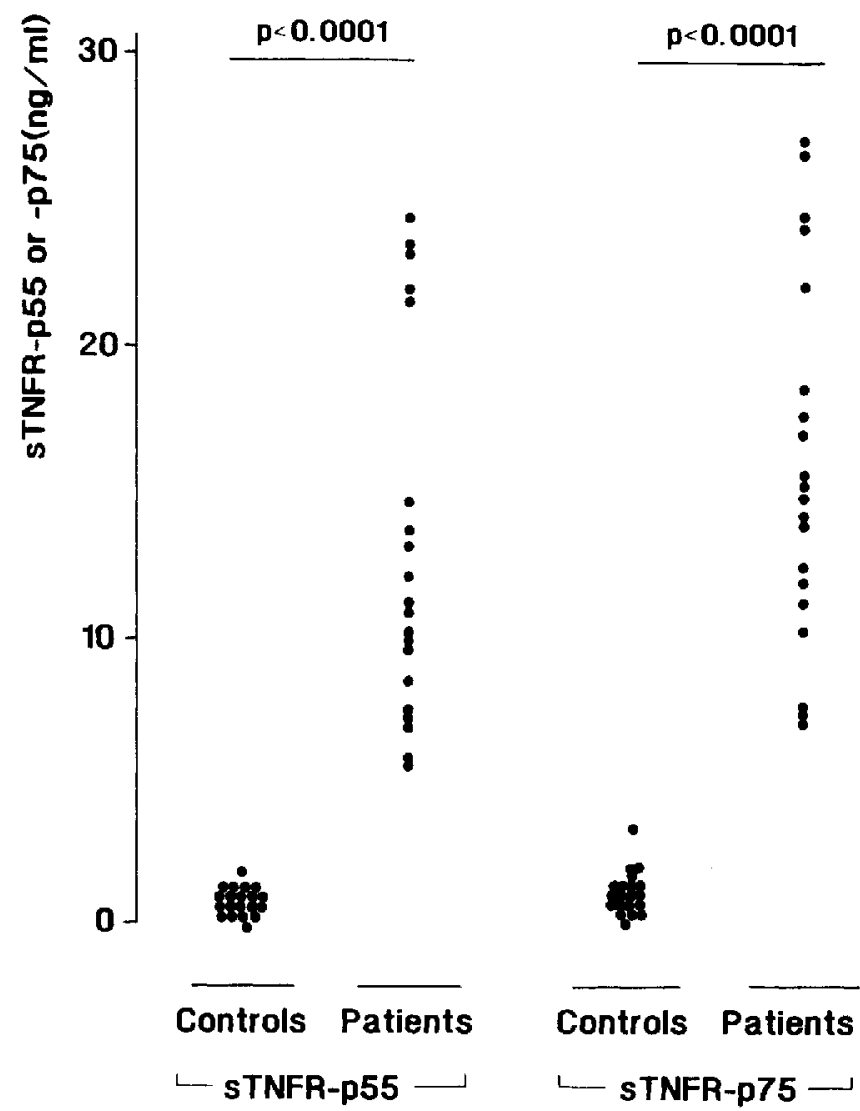

Figure 1. Serum concentrations of sTNFR-p 55 and sTNFR-p 75 in 20 healthy humans and 20 patients with clinical sepsis.

courses were highly suggestive of an ongoing infection. The duration of illness before blood was obtained was $1-41 \mathrm{~h}$ (13 \pm 3 ).

The serum concentrations of both types of sTNFRs were markedly elevated in all patients with sepsis compared with those of healthy controls (figure I). In patients, the serum levels of sTNFR-p 55 were $13.2 \pm 1.4 \mathrm{ng} / \mathrm{mL}$ versus $1.0 \pm$ $0.3 \mathrm{ng} / \mathrm{mL}$ in controls $(P<.0001)$. Serum sTNFR-p 75 concentrations were $16.0 \pm 1.4$ and $1.5 \pm 0.6 \mathrm{ng} / \mathrm{mL}$, respectively $(P<.0001)$. In septic patients, the levels of sTNFRp55 correlated significantly with simultaneously measured levels of immunoreactive TNF $(103 \pm 26 \mathrm{pg} / \mathrm{mL} ; r=.63, P$ $<.01$; figure 2, top). sTNFR-p75 levels also correlated with immunoreactive TNF concentrations $(r=.69, P<.001$; figure 2 , middle). The levels of TNF activity $(45 \pm 31 \mathrm{pg} /$ $\mathrm{mL}$ ) showed no significant correlations with sTNFRs concentrations (data not shown). Serum levels of sTNFR-p55 correlated with those of sTNFR-p $75(r=.83, P<.001$; figure 2 , bottom). In this small cohort, the values of TNF and its soluble receptors did not differ significantly between surviving and nonsurviving patients (data not shown). In addition, no significant correlations were found between Apache II scores and duration of illness and concentrations of TNF and sTNFRs (data not shown). TNF was not detectable in the circulation of the healthy controls.
Modulation of endotoxin-induced STNFR release through inhibition of the TNF response by pentoxifylline. In a series of experiments in chimpanzees, we investigated whether intermediate TNF production was necessary for the induction of sTNFR release in experimental endotoxemia. For this purpose, pentoxifylline was used because of its known ability to inhibit endotoxin-induced production of TNF in vitro and in vivo $[27,28]$. Pentoxifylline markedly attenuated TNF release after injection of endotoxin in chimpanzees. Peak TNF concentrations, found after $90 \mathrm{~min}$ in all animals, were 271 $\pm 26 \mathrm{pg} / \mathrm{mL}$ after endotoxin alone and $55 \pm 23 \mathrm{pg} / \mathrm{mL}$ after endotoxin in combination with pentoxifylline $(P<.05$, difference between the two treatment groups). Pentoxifylline reduced endotoxin-induced TNF bioactivity $(111 \pm 64$ vs. $40 \pm 23 \mathrm{pg} / \mathrm{mL}$ ).

Baseline serum levels of sTNFRs in the chimpanzees were similar to those in humans. In addition, endotoxin produced
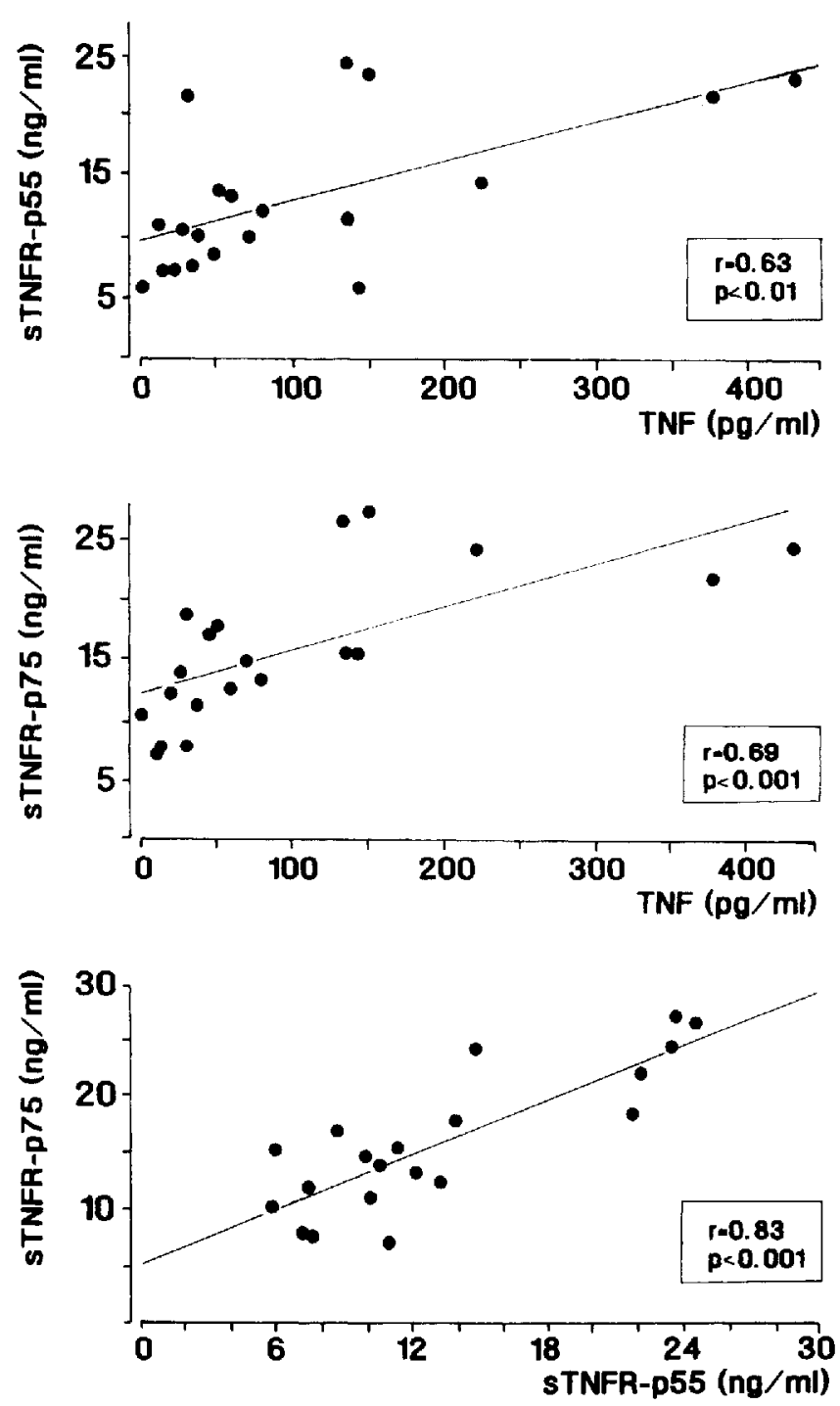

Figure 2. Correlations between serum concentrations of TNF, sTNFR-p55, and sTNFR-p 75 in 20 patients with clinical sepsis. 

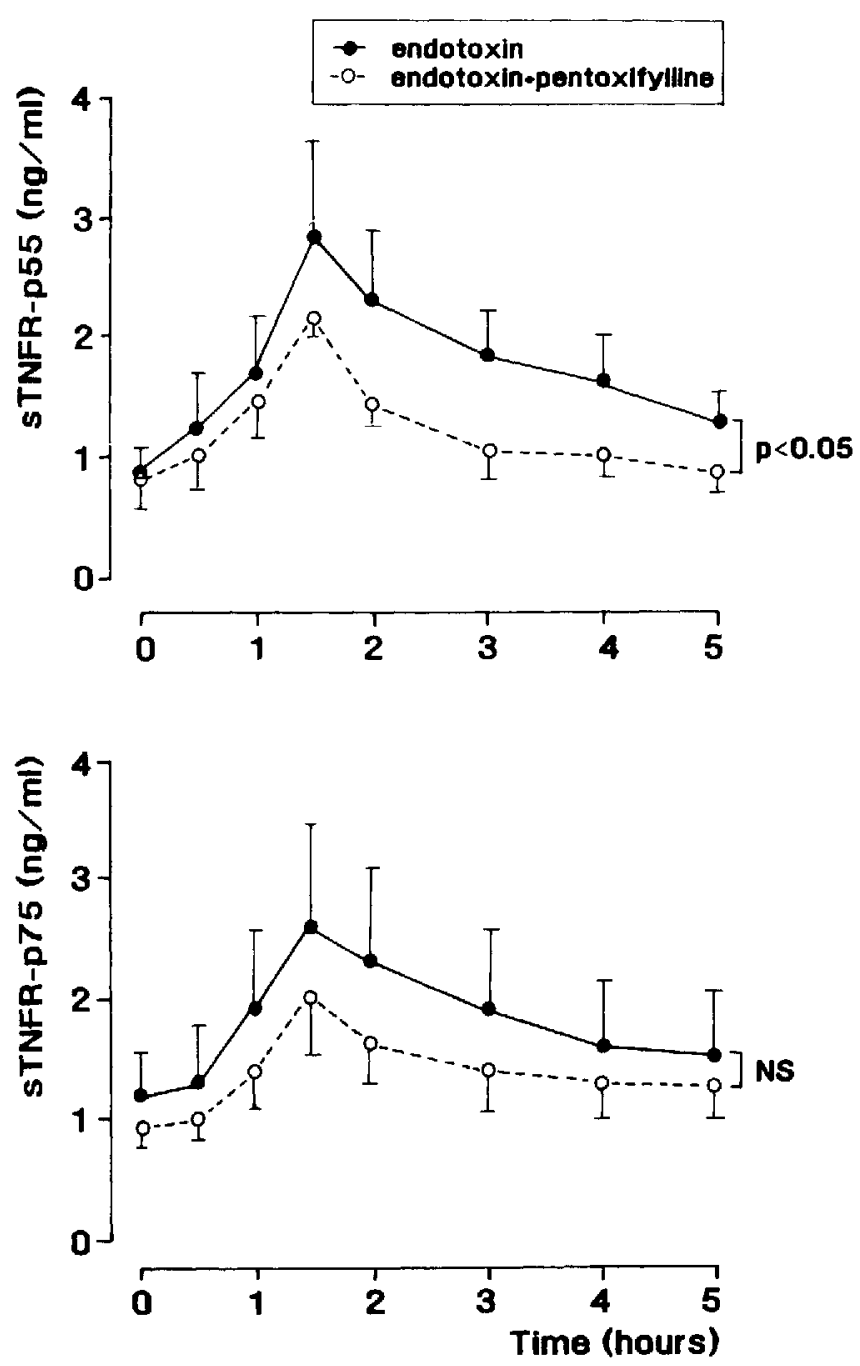

Figure 3. Mean ( \pm SE) serum concentrations of sTNFR-p 55 and sTNFR-p 75 after intravenous administration of Escherichia coli endotoxin ( $4 \mathrm{ng} / \mathrm{kg} ; n=4$ ) or $E$. coli endotoxin ( $4 \mathrm{ng} / \mathrm{kg}$ ) combined with a 3-h infusion of pentoxifylline (total dose, $500 \mathrm{mg}$ ), starting $30 \mathrm{~min}$ before endotoxin injection $(n=3)$, in chimpanzees.

release of both sTNFRs with kinetics comparable to those in humans [17]. Pentoxifylline blunted the endotoxin-induced appearance of sTNFR-p55 (peak concentrations $2.9 \pm 0.9$ $\mathrm{ng} / \mathrm{mL}$ after endotoxin alone vs. $2.3 \pm 0.1 \mathrm{ng} / \mathrm{mL}$ after endotoxin with pentoxifylline; $P<.05$ ) and reduced the release of sTNFR-p75 $(2.6 \pm 1.0$ vs. $2.0 \pm 0.4 \mathrm{ng} / \mathrm{mL}$, respectively; $P$ $=.12$ ) (figure 3 ).

\section{Discussion}

sTNFRs represent soluble forms of the extracellular domains of the cell surface receptors for TNF and probably arise by proteolytic cleavage. It has been suggested that TNF itself, in an autocrine manner, is involved in the induction of sTNFR release. This supposition originates from the observations that intravenous injection of endotoxin into normal humans induces subsequent rises in the circulating levels of TNF and both soluble receptors [17] and that infusion of recombinant TNF into cancer patients results in a more rapid rise in TNF-binding protein concentrations than found in experimental endotoxemia [19].

The present study sought further insight into the role of TNF in the systemic release of its soluble receptors in sepsis. In patients with sepsis, the extent of the release of both sTNFR-p55 and sTNFR-p 75 significantly correlated with immunoreactive (total) TNF levels. In chimpanzees, pentoxifylline, a xanthine derivative that has been reported to directly block endotoxin-induced TNF production at the level of transcription of the TNF gene [27], reduced the TNF response to intravenous endotoxin to $20 \%$ of the response observed after administration of endotoxin alone. However, pentoxifylline only slightly decreased the appearances of sTNFRs, and was statistically significant only for the p55 form. Therefore, our results suggest either that TNF may not be an important factor in the secretion of sTNFRs in systemic infection or that TNF is involved in the endotoxin-induced appearance of its soluble receptors in a nonlinear fashion, that is the small amount of TNF remaining in the circulation in animals treated with pentoxifylline may have had a disproportionally large effect on the induction of sTNFRs.

The septic patients had considerably higher levels of sTNFRs than did the endotoxemic chimpanzees, despite lower TNF concentrations. Possibly this apparent discrepancy resulted because the chimpanzees had frequent blood sampling, which showed the peak TNF levels, but in the patients the maximal TNF concentration may have been missed because of the very short serum half-life of the cytokine. In contrast, levels of sTNFRs are more stable and do not return to baseline as rapidly as does TNF. Thus, the greater elevation of sTNFRs in the patients with sepsis than in the endotoxin-treated chimpanzees probably reflects the more severe bacterial challenge in the first group.

The mechanisms by which the presently observed appearances of sTNFRs occur at cellular levels remain to be established. In vitro, shedding of TNF receptors can be induced by several agents including phorbol esters C5a and A23187 $[12,29]$. Moreover, TNF itself can provoke the production of a sTNFR by HL-60 cells [12]. A rapid increase in sTNFR$\mathrm{p} 55$ after a bolus intravenous injection of heparin into normal humans has been observed, suggesting that sTNFRs are present in vivo in a storage pool from which they can be secreted after stimulation [30].

sTNFRs may have a dual function in the body. They retain their affinity for TNF and therefore compete with cellassociated TNF receptors for binding of free TNF. The eventual effect of the formation of STNFR-TNF complexes likely depends on the concentrations of the substances and the rate at which sTNFRs and TNF are cleared from the site of action of the cytokine. In body compartments from which TNF is 
cleared slowly, sTNFRs may serve as carriers for this protein and even augment its effects by stabilizing its structure and prolonging its activity [31]. In the circulation, however, from which TNF is cleared with a very short half-life [6], sTNFRs probably mainly act as inhibitors of excessive TNF activity, especially when they are present in relatively high concentrations [17, 31]. Indeed, several in vitro studies have reported significant inhibition of TNF activity by sTNFRs when present at a 10- to 100-fold molar excess, depending on the bioassay used $[12,17,24,31]$. In addition, administration of recombinant sTNFR-p55 to baboons with lethal bacteremia attenuates hemodynamic collapse and cytokine release [17]. In our patients with sepsis, sTNFRs circulated in up to $90-$ fold molar excess over TNF. Taken together, it is likely that in sepsis the shedding of the extracellular parts of membranebound TNF receptors represents a host defense mechanism. Apparently, this inhibitory system is in many cases insufficient to prevent the lethal consequences of high blood concentrations of TNF. Increasing the levels of sTNFRs by exogenous administration of recombinant or chimeric forms of those proteins may therefore prove to be beneficial for the outcome of sepsis $[17,32,33]$.

In conclusion, our study demonstrates that the levels of sTNFR-p55 and $-p 75$ are elevated in patients with clinical sepsis. In chimpanzees, strong inhibition of the TNF response to endotoxin by treatment with pentoxifylline only slightly reduced the simultaneously measured circulating sTNFRs. Our results therefore indicate that if TNF is involved in the induction of the systemic release of its own soluble receptors in sepsis, the dose-effect relationship is likely to be nonlinear.

\section{Acknowledgments}

We thank Bart L. Haagmans for measurement of TNF activity, Gerdie Wentink for preparing the illustrations, and Marieke Kat for typing the manuscript.

\section{References}

1. Sherry B, Cerami A. Cachectin/tumor necrosis factor exerts endocrine, paracrine and autocrine control of inflammatory responses. J Cell Biol 1988;107:1269-77.

2. Tracey KJ, Fong Y, Hesse DG, et al. Anti-cachectin/TNF monoclonal antibodies prevent septic shock during lethal bacteraemia. Nature 1987;330:662-4.

3. Waage A, Halstensen A, Espevik T. Association between tumour necrosis factor in serum and fatal outcome in patients with meningococcal disease. Lancet 1987;329:355-7.

4. Girardin E, Grau GE, Dayer JM, et al. Tumor necrosis factor and interleukin $I$ in the serum of children with severe infectious purpura. N Engl J Med 1988;319:397-400.

5. Tracey $\mathrm{K}$, Beutler B, Lowry SF, et al. Shock and tissue injury induced by recombinant human cachectin. Science 1986:234:470-4.

6. van der Poll T, Büller HR, ten Cate $H$, et al. Activation of coagulation after administration of tumor necrosis factor to normal subjects. $\mathrm{N}$ Engl J Med 1990;322:1622-7.
7. Seckinger P, Isaaz S, Dayer JM. A human inhibitor of tumor necrosis factor $\alpha$. J Exp Med 1988; 167:1511-6.

8. Peetre C, Thysell H, Grubb A, Olsson I. A tumor necrosis factor binding protein is present in human biological fluids. Eur $\mathbf{J}$ Haematol 1988:41:414-9.

9. Olsson I. Lantz M, Nilsson E, et al. Isolation and characterization of a tumor necrosis factor binding protein from urine. Eur J Haematol 1989;42:270-5.

10. Seckinger P, Isaaz S, Dayer JM. Purification and biologic characterization of a specific tumor necrosis factor $\alpha$ inhibitor. J Biol Chem 1989;264:11966-73.

11. Engelmann H. Aderka D, Rubinstein M, Rotman D, Wallach D. A tumor necrosis factor-binding protein purified to homogeneity from human urine protects cells from tumor necrosis factor toxicity. J Biol Chem 1989;264:1 1974-80.

12. Lantz M, Gullberg U. Nilsson E, Olsson I. Characterization in vitro of a human tumor necrosis factor-binding protein. A soluble form of a tumor necrosis factor receptor. J Clin Invest 1990;86:1396-1402.

13. Loetscher H, Pan YCE, Lahm HW, et al. Molecular cloning and expression of the human $55 \mathrm{kD}$ tumor necrosis factor receptor. Cell 1990;61:351-9.

14. Schall TJ, Lewis M, Koller KJ, et al. Molecular cloning and expression of a receptor for tumor necrosis factor. Cell 1990;61:361-70.

15. Kohno T, Brewer MT, Baker SL, et al. A second tumor necrosis factor receptor gene product can shed a naturally occurring tumor necrosis factor inhibitor. Proc Natl Acad Sci USA 1990;87:833l-5.

16. Dembic $Z$, Loetscher $H$, Gubler $U$. et al. Two human TNF receptors have similar extracellular, but distinct intracellular, domain sequences. Cytokine 1990:2:231-7.

17. van Zee KJ, Kohno T, Fischer E, Rock SC, Moldawer LL. Lowry SF. Tumor necrosis factor soluble receptors circulate during experimental and clinical inflammation and can protect against excessive tumor necrosis factor $\alpha$ in vitro and in vivo. Proc Natl Acad Sci USA 1992;89:4845-9.

18. van Deventer SJH, Büller HR, ten Cate JW, Aarden LA, Hack CE, Sturk A. Experimental endotoxemia in humans: analysis of cytokine release and coagulation, fibrinolytic and complement pathways. Blood 1990;76:2520-6.

19. Lantz M, Malik S, Slevin M. Olsson I. Infusion of tumor necrosis factor (TNF) causes an increase in circulating TNF-binding protein in humans. Cytokine 1990;2:402-6.

20. Girardin E. Roux-Lombard P, Grau GE. et al. Imbalance between tumor necrosis factor- $\alpha$ and soluble TNF receptor concentrations in severe meningococcaemia. Immunology 1992;76:20-3.

21. Ziegler EJ, Fischer CJ. Sprung CL. et al. Treatment of gram-negative bacteremia and septic shock with HA-1A human monoclonal antibody against endotoxin. N Engl J Med 1991;324:429-36.

22. Brockhaus M, Schoenfeld HJ, Schlaeger EJ, Hunziker W, Lesslauer W, Loetscher $\mathrm{H}$. Identification of two types of tumor necrosis factor receptors on human cell lines by monoclonal antibodies. Proc Natl Acad Sci USA 1990;87:3127-31.

23. Digel W, Porzsolt F, Schmid M, Herrmann F, Lessiauer W, Brockhaus $M$. High levels of circulating soluble receptors for tumor necrosis factor in hairy cell leukemia and type B chronic lymphocytic leukemia. J Clin Invest 1992;89:1690-3.

24. Brockhaus M, Bar-Khayim Y, Gurwicz S. Frensdorff A. Hara N. Plasma tumor necrosis factor soluble receptors in chronic renal failure. Kidney Int 1992;42:663-7.

25. Engelberts I, Stephens S, Francot GJM, van der Linden CJ. Buurman WA. Evidence for different effects of soluble TNF-receptors on various TNF measurements in human biological fluids. Lancet 1991;338:515-6. 
26. Espevik T, Nissen-Meyer J. A highly sensitive cell line, WEHI 164 clone 13, for measuring cytotoxic factor/tumor necrosis factor from human monocytes. J Immunol Methods 1986;95:99-105.

27. Strieter RM, Remick PA, Ward PA, et al. Cellular and molecular regulation of tumor necrosis factor $\alpha$ production by pentoxifylline. Biochem Biophys Res Commun 1988; 155:1230-6.

28. Zabel P, Wolter DT, Schönharting MM, Schade UF. Oxpentifylline in endotoxaemia. Lancet 1989;334:1474-7.

29. Porteu F, Nathan C. Shedding of tumor necrosis factor receptors by activated human neutrophils. J Exp Med 1990;172:599-607.

30. Lantz M, Thysell H, Nilsson E. Olsson I. On the binding of tumor necrosis factor (TNF) to heparin and the release in vivo of the TNFbinding protein I by heparin. J Clin Invest 1991;88:2026-31.

31. Aderka D, Engelmann H, Maor Y, Brakebusch C, Wallach D. Stabilization of the bioactivity of tumor necrosis factor by its soluble receptors. J Exp Med 1992;175:323-9.

32. Lesslauer W, Tabuchi H, Gentz R, et al. Recombinant soluble tumor necrosis factor proteins protect mice from lipopolysaccharide-induced lethality. Eur J Immunol 1991;21:2882-6.

33. Ashkenazi A, Marsters S, Capon DJ, et al. Protection against endotoxin shock by a tumor necrosis factor receptor immunoadhesin. Proc Natl Acad Sci USA 1991;88:10535-9. 